\title{
The effect of mutual cooperation values towards people's lifestyle in the form of maps
}

\author{
Febriani $^{\mathrm{a}}$, Adhis Tessa ${ }^{\mathrm{b}}$, Ridho Utami ${ }^{\mathrm{a}}$, Wipsar Sunu Brams Dwandaru ${ }^{\mathrm{a}}$ \\ a Physics Education Department, Universitas Negeri Yogyakarta, Yogyakarta, Indonesia \\ ${ }^{\text {b }}$ Sociology Education Department, Universitas Negeri Yogyakarta, Yogyakarta, Indonesia
}

\begin{abstract}
ABSTRAK
Gotong-royong merupakan nilai budaya yang menjadi identitas dan dasar dari bangsa Indonesia. Akan tetapi, saat ini gotong-royong mengalami pergeseran yang berpengaruh terhadap pola hidup masyarakat Indonesia, khususnya dalam hal ini sifat individualis. Tujuan penelitian ini adalah mempelajari pengaruh nilai gotong-royong terhadap pola hidup masyarakat di Kelurahan Tamanan, Banguntapan, Bantul, Daerah Istimewa Yogyakarta (DIY) dalam bentuk peta dan pengaruhnya terhadap sifat individualis masyarakat. Metode penelitian yang digunakan adalah metode kualitatif dan kuantitatif (metode campuran). Metode campuran dilakukan melalui wawancara dan survei dengan warga desa Tamanan di sembilan padukuhan. Berdasarkan peta gotong-royong diperoleh hasil bahwa padukuhan yang paling kuat nilai gotong-royong adalah Kragilan, Kerobokan, dan Glagah Kidul. Sedangkan padukuhan dengan nilai gotong-royong yang paling lemah ada di Rejokusuman dan Tamanan. Hal ini menunjukkan bahwa kuat-lemahnya nilai gotong-royong tidak bergantung pada jauh-dekatnya letak padukuhan tersebut dari Kota Yogyakarta. Selanjutnya peta gotong-royong ini berbanding terbalik dengan peta sifat individualis dalam masyarakat, yakni semakin kuat nilai gotong-royong dalam masyarakat semakin lemah sifat individualis dalam masyarakat.
\end{abstract}

\section{ABSTRACT}

The Effect of Mutual Cooperation Values Towards People's Lifestyle in the Form of Maps. Mutual cooperation is a cultural value that becomes the identity and basis of the Indonesian nation. However, currently mutual cooperation underwent a shift that may affect the lifestyle of the Indonesian people, especially in this case individual behavior. The objective of this research is to study the effect of mutual cooperation towards people's individual behavior in Tamanan village, Banguntapan, Bantul, Special Region of Yogyakarta (DIY) in the form of maps and its effect towards the individual behavior of the community. The research method used is qualitative and quantitative methods (mixed method). Qualitative and quantitative methods have been carried out through interviews and surveys with villagers in nine hamlets of Tamanan village. Based on the mutual cooperation map the results obtained from this study show that Kragilan, Kerobokan, and Glagah Kidul hamlets have the strongest mutual cooperation values, whereas Rejokusuman and Tamanan hamlets have the weakest mutual cooperation values. This shows that the strength of mutual cooperation does not depend on the proximity of the hamlets from the city of Yogyakarta. Moreover, the mutual cooperation map is reciprocal to the individual behavior of the people in the hamlets, i.e.: the stronger the mutual cooperation values the weaker the individual behavior.

\section{Sejarah Artikel}

Diterima : 14 Januari 2020

Disetujui : 30 April 2020

\section{Kata kunci:}

Peta Gotong-royong

Pola hidup masyarakat

\section{Keywords:}

Mutual Cooperation Map, People's Lifestyle, Individualist Lifestyle

\section{Introduction}

Indonesia was born on the basis of mutual cooperation. The philosophy of the Indonesian nation, which is contained in five precepts in the Pancasila can be squeezed into one term, namely mutual cooperation. Therefore, preservation of the mutual cooperation culture in the community should continue to be carried out to maintain the standing of the Republic of Indonesia.

The study of mutual cooperation can be traced since Bowen (1986) examined the political construction of the Indonesia community's mutual cooperation tradition. Mutual cooperation arises

Korespondensi: Wipsar Sunu Brams Dwandaru, wipsarian@uny.ac.id, Physics Education Department, Universitas Negeri Yogyakarta,

Yogyakarta, Indonesia

Copyright (C) 2020. Jurnal Civics: Media Kajian Kewarganegaraan. 
from the encouragement, awareness, and enthusiasm to work and bear the consequences of simultaneously working together without regard to religion, ethnicity, race, without thinking and prioritizing benefits for themselves (Effendi, 2013; Sudrajat, 2014). Cultural values in mutual cooperation contain four concepts, namely: 1) humans cannot live alone in this world, but surrounded by their society, 2) humans depend upon each other, 3) humans should maintain a good relationship with each other, and 4) humans should have empathy toward each other. These cultural values can be summarized into two main values, i.e.: mutual cooperation and solidarity. Mardiasmo \& Barnes (2015) state that mutual cooperation has become a key cultural function in Indonesia. Based on the current social conditions, the function of mutual cooperation is an important medium for social interaction. Mutual cooperation may become a unifier between different communities in terms of religion, ethnicity, race, and groups. The presence of mutual cooperation can actually be a medium for mutual interaction and may reduce existing conflicts. Moreover, Koentjaraningrat (1961) states that via the mutual cooperation various problems in our daily activities could easily and cheaply overcome.

However, mutual cooperation is currently experiencing a shift in its values. This is caused by various social changes, such as the development of technology and information industry as well as the increasingly complex activities level of society that influences people's lifestyle in the community itself. Another aspect that may cause the mutual cooperation to shift its values is globalization (Sari, 2015). The study of globalization towards mutual cooperation values has been conducted by Suneki (2012). Anggorowati \& Sarmini (2015) further examine mutual cooperation in the global era and suggested two efforts so that mutual cooperation can be maintained, viz.: through voluntary or coercive means. Moreover, the flow of modernization has an effect on existing technological devices so that the equipment used for mutual cooperation activities are replaced by modern equipment that are faster in its working process. Thus, the mutual cooperation no longer uses people's power (non-material), but is replaced by money (material) [Sari, 2015]. In fact, the disappearance of mutual cooperation culture in the era of globalization has given rise to a new form of mutual cooperation in social media called crowd funding and has been studied by Irfan (2017).

The shift in the values of mutual cooperation can also be caused by interactions between rural and urban areas. This shift occurs spatially from rural areas to urban areas. In urban areas the behavior of mutual cooperation is increasingly rare because the community submits work to an event organizer or a group that is paid to complete the work to make it more practical (Rochmadi, 2016). The lifestyle factors of the city (urban area), which are consumptive and hedonistic causes shifts in mutual cooperation values. However, the mutual cooperation which should exist in the rural area is now slowly begins to decrease. In fact, social values, which are more individualistic coupled with materialistic behavior, start to occur. Of course, this has caused the public to increasingly indulge in individual behavior that is not in accordance with the ideals of the founding fathers and consequently will weaken the state of the Republic of Indonesia, which is then vulnerable to disintegration.

In this study, we would like to report the mutual cooperation values shift and its effect towards the individual behavior in the community. The discussion is based upon maps of the mutual cooperation and individual behavior obtained from data gathering in the study. The region being studied is Tamanan village in Bantul District, Yogyakarta. This village extends from the north to the south of Yogyakarta, consisting of nine hamlets. This village is chosen, as it is a unique location, where the northern part of the village is near city (urban area) of Yogyakarta, and the southern part is rural region. Hence, it is interesting to discuss the spatial shift of mutual cooperation values in the region and its effect on the individual behavior of the people in the village. 


\section{Methods}

This Study uses mixed method based on Creswell (2009), namely qualitative and quantitative methods. The method is used because this study requires qualitative and quantitative analysis in drawing the conclusions. The model that has been used is a sequential exploratory model where qualitative method is carried out first and then followed by the quantitative method. The qualitative method in this study uses a grounded theory data analysis approach, whereas the quantitative method uses a descriptive statistical data analysis approach.

The data collection technique is done in ways that are shared in the qualitative and quantitative methods together. In the capacity of the qualitative method, the data collection technique is carried out by interview, observation, documentation, and literature study. For the quantitative method, the data collection technique is aimed at the object of the study with respondents through statistics whose sample is determined purposively. The research variables in this study may be observed in Table 1.

Table 1

Research Variables in This Study

\begin{tabular}{|c|c|c|c|c|}
\hline No. & Variable & Factor & Indicator & $\begin{array}{c}\text { Questionnaire Item } \\
\text { Number }\end{array}$ \\
\hline \multirow[t]{10}{*}{1.} & Mutual & Frequency & Weekly & 25 \\
\hline & cooperation & & Monthly & 24 \\
\hline & values (X) & & Incidental & 27 \\
\hline & & & Specific events & 28 \\
\hline & & Participants & All residents & 18 \\
\hline & & & $\begin{array}{l}\text { Community } \\
\text { leaders }\end{array}$ & 13 \\
\hline & & & $\begin{array}{l}\text { Certain age } \\
\text { groups }\end{array}$ & 10 \\
\hline & & & Gender & 8 \\
\hline & & Contribution & Physique & 31 \\
\hline & & & Material & 20 \\
\hline
\end{tabular}

2. People's lifestyle Characteristics of Collectiveness 19, 21, 25, 26, 30, 33

(Y) the community Individualist 19, 23, 27, 30, 34

Source: Data from author, 2018.

The population of this study is the community of Tamanan village, Banguntapan, Bantul, DIY, which is over 15 years old. The population obtained from the local government data in Bantul Regency is 9576 people. The sampling technique for the qualitative method is purposive sampling. The technique of collecting data via interviews is conducted on nine (9) hamlet leaders who are considered to know the conditions of their own hamlet and five (5) residents. The sampling technique in the quantitative method is proportionate stratified random sampling because the population level of the Tamanan village is proportional. The level referred to in this study are groups of the 9 hamlets found in Tamanan village, while the sample size of 338 people was selected based on Isaac and Michael's table with a precision level of $5 \%$ (see Table 2).

Table 2

Number of Residents above the age of 15 years old as samples

\begin{tabular}{lccc}
\hline \multicolumn{1}{c}{ Hamlet } & $\begin{array}{c}\text { Population Number } \\
\text { per Hamlet }\end{array}$ & Sample Calculation & $\begin{array}{c}\text { Sample } \\
\text { Number }\end{array}$ \\
\hline Kragilan & 1388 & $(1388 / 9576) \times 336=48.70$ & 49 \\
Glagah Lor & 874 & $(874 / 9576) \times 336=30.67$ & 31 \\
Glagah Kidul & 883 & $(883 / 9576) \times 336=30.98$ & 31
\end{tabular}




\begin{tabular}{lccc}
\hline Hamlet & $\begin{array}{c}\text { Population Number } \\
\text { per Hamlet }\end{array}$ & Sample Calculation & $\begin{array}{c}\text { Sample } \\
\text { Number }\end{array}$ \\
\hline Krobokan & 952 & $(952 / 9576) \times 336=34.12$ & 34 \\
Kauman & 926 & $(926 / 9576) \times 336=32.49$ & 32 \\
Grojogan & 830 & $(830 / 9576) \times 336=29.12$ & 29 \\
Tamanan & 1297 & $(1297 / 9576) \times 336=45.51$ & 46 \\
Dladan & 1219 & $(1219 / 9576) \times 336=42.77$ & 43 \\
Rejokusuman & 1275 & $(1275 / 9576) \times 336=42.70$ & 43 \\
Total & 9576 & 337.06 & 338 \\
\hline
\end{tabular}

Source: Local Government Data of Bantul Regency Semester 2, 2018.

We have carried out descriptive data analysis, so that the strength of the qualitative narrative is in the depth of the data and analysis of the data. Qualitative description narratives are then supported by quantitative data that have been analyzed with descriptive statistical approaches through the help of tabulation of data using MS Excel. The results of the statistical analysis are then juxtaposed with the qualitative narratives. This mixed method process has been carried out in several stages, namely: i) transcribing the quantitative and qualitative data, ii) coding the data, iii) sorting the data according to the need to answer the objectives of the study, iv) testing the quantitative data statistically, $v$ ) interpreting the existing data by looking at the connectedness of the data with the theory so that an in-depth and systematic analysis process is produced, and vi) writing it in narrative form so that it can reveal the depth of the data information and strong in analysis.

The process of drawing the conclusions for the research objective is to make a map of the mutual cooperation in Tamanan village obtained from the results of qualitative description analysis. Furthermore, the mutual cooperation map is then verified further by the results of the statisticdescriptive analysis from the quantitative method. The maps are modified into a color gradation maps to show the shift in the mutual cooperation at the research site. Furthermore, to strengthen the qualitative data we used the results of descriptive statistical analysis in the form of data tabulation. The last stage is conducting data interpretation and drawing conclusions. The conclusions are obtained from qualitative and quantitative data that has been previously reduced.

\section{Results and Discussion}

This study began in March 2019. The study begins with conducting initial observations to the research site. This is done by arranging the necessary permits and conducting direct observations in Tamanan village, Bantul, DIY. The permit letter is obtained by giving an introduction letter to the Tamanan vllage office then from the village office giving a copy of the letter as an introduction to each hamlet in Tamanan village to carry out the permits. In addition, we also arrange permits to obtain primary data on the population of Tamanan village per hamlet over the age of 15 years old at local government office of Bantul, DIY. The results of this primary data are as shown in Table 2.

The next activity is improving the qualitative and quantitative instruments, which are then validated by two reviewers, namely Dr. Pujianto (Physics Education Department) and Adi Cilik Pierawan, PhD (Sociology Education Department); both are lecturers of Universitas Negeri Yogyakarta. After that, a revision is carried out in accordance with the input from the two validators. The instrument validation is done by one shoot technique so that we took the data using the instrument. Retrieval of the data is conducted as follows. First, interviewing 9 leaders of the hamlets in Tamanan village. Furthermore, transcripts, data reduction, codification, and analysis are carried out. Based on the study that has been done qualitatively a hypothesis is found regarding mutual cooperation activities in each hamlet in Tamanan village. Second, the quantitative method is used to prove the hypothesis by distributing questionnaires to the respondents. The quantitative data is processed to test the validity and reliability of the instrument and we obtain that the instrument is 
Febriania, Adhis Tessab, Ridho Utamia, Wipsar Sunu Brams Dwandaru. The effect of mutual cooperation values towards people's lifestyle in the form of maps

valid and reliable. Moreover, the data is processed by tabulation to find out the mutual cooperation behavior of the community and people's lifestyle, especially individual behavior that is formed in each hamlet in Tamanan village. As mentioned previously, Tanaman village consists of 9 (nine) hamlets, viz.: Kragilan, Rejokusuman, Tamanan, Dladan, Kauman, Krobokan, Grojogan, Glagah Lor, and Glagah Kidul.

Based on the results of the data analysis obtained through qualitative and quantitative methods the result in this study is a map of the mutual cooperation in Tamanan village, which is given in Figure 2. The map is obtained based on the results of interviews conducted on 9 hamlet leaders and of questionnaires to several communities in Tamanan village. Moreover, we also obtained the map of individual behavior level, which may be observed in Figure 3. The map is also obtained from the interviews and questionnaires.

The map below (Figure 2) is made with the rules of color gradation where the dark blue indicates mutual cooperation in the hamlet is still strong, while the lighter blue color shows a weaker mutual cooperation in the village. Hence, the lighter the blue colors the weaker the mutual cooperation. The results of this observation are interesting because there is a hamlet near the city of Yogyakarta where the mutual cooperation is still strong, i.e.: Kragilan and Krobokan. Thus, the assumption so far that the spatial shift in the value of mutual cooperation is getting weaker when approaching the city of Yogyakarta is not observed or false.

Figure 2

Map of mutual cooperation in Tamanan village, Bantul, DIY.

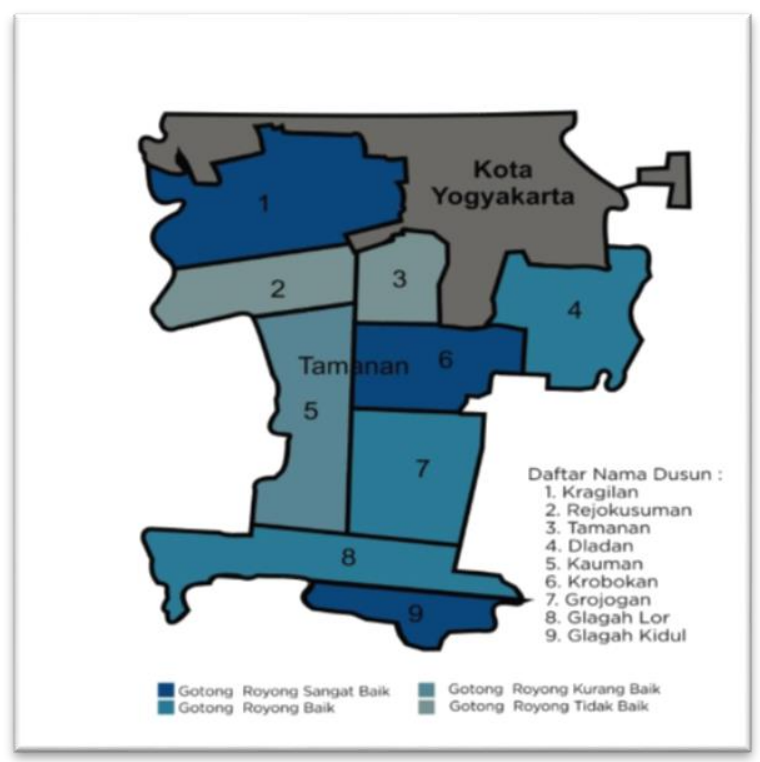

Figure 3

Individual behavior map of Tamanan village,

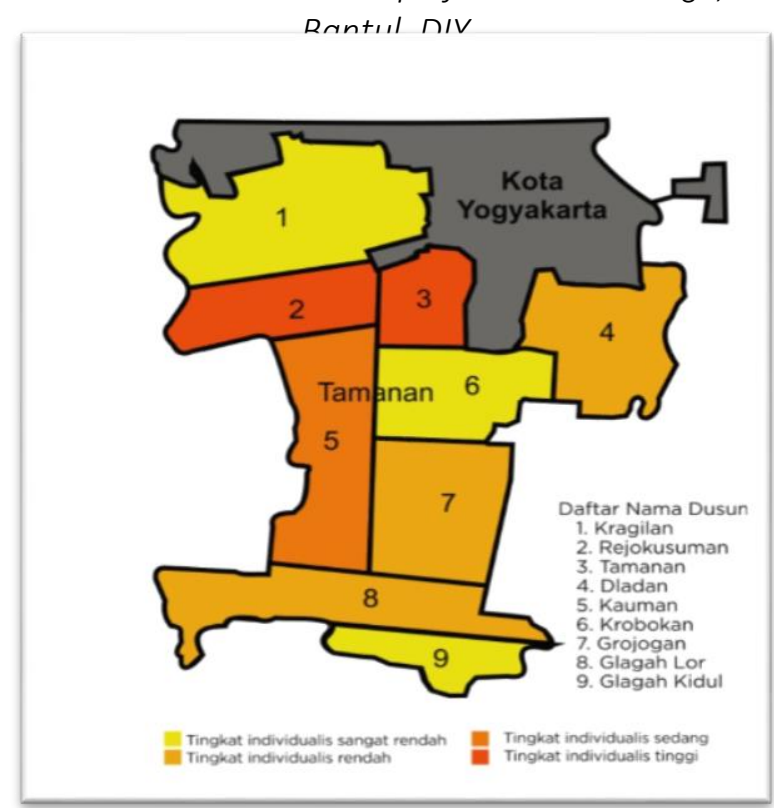

Furthermore, Figure 2 shows that Glagah Kidul (9), Krobokan (6), and Kragilan (1) is dark blue in color, which shows the value of mutual cooperation is still strong. This is reinforced by the quantitative data, which produce $97 \%, 86 \%$, and $91 \%$ of the people in the three hamlets, i.e.: Glagah Kidul, Krobokan, and Kragilan, respectively, always participate in the mutual cooperation activities. The hamlet of Glagah Kidul has the highest mutual cooperation activities, i.e. 97\%, as it is the most rural area (southern part) of the Tamanan village. Hence, it is obvious that the mutual cooperation is still very high.

On the other hand, Glagah Lor (8), Grojogan (7), and Dladan (4) are light blue colored, which indicates that the mutual cooperation begin to diminish. This is reinforced by the quantitative data 
that produce $74 \%, 72 \%$, and $61 \%$ of the people in the three hamlets, i.e.: Glagah Lor, Grojogan, and Dladan, respectively, often participate in the mutual cooperation activities. These results show that the mutual cooperation activities in Glagah Kidul, Krobakan, and Kragilan are higher than in Glagah Lor, Grojogan, and Dladan. This means that the community in Glagah Lor, Grojogan, and Dladan may be affected by behavior of the community in the urban region, which is more likely to decrease the mutual cooperation.

Furthermore, the Kauman (5) hamlet is lighter in color, which indicates that the mutual cooperation in the hamlet is diminishing. This is reinforced by the quantitative data, which produces only $43 \%$ of the people who always participate in the mutual cooperation activities. The lowest mutual cooperation activities occur in the Rejokusuman (2) and Tamanan (3), which can be observed in the faded (most light) blue color. This is again reinforced by the quantitative data, which yields only $23 \%$ of the people in both hamlets always participate in the mutual cooperation activities. It may be observed that Rejokusuman and Tamanan hamlets are also nearest to the city of Yogyakarta. Hence, the low mutual cooperation in these two hamlets is in accordance with the study of Gea (2016).

It can be observed that because almost half of the hamlets near the city of Yogyakarta have high mutual cooperation, then the decrease in mutual cooperation activities is not influenced by the proximity or distance of the hamlets to the city of Yogyakarta. This means that the proximity of the hamlets to the city does not mean that the mutual cooperation is diminishing, although Gea (2016) states that mutual cooperation behavior is increasingly rare and difficult to find especially in urban areas. It is precisely in the Kragilan hamlet (1), which is closest to the city of Yogyakarta, that still has strong mutual cooperation as in the Glagah Kidul (9), which is the farthest from the city. This means that there are efforts by the Kragilan, Krobokan, dan Dladan hamlets to counter the negative effect of the individual behavior of the city so that the mutual cooperation is high in the three hamlets. Several reasons have been given by Febriani, et al. (2019) that may determine the mutual cooperation values shift in the village, i.e.: i) the high (daily) activities of the community, ii) leader activeness, and iii) migration of people. The first aspect, i.e. high community activities, especially in the urban areas tends to decrease the mutual cooperation, which may be the reason of low mutual cooperation in the Rejokusuman and Tamanan hamlets. The second aspect, leader activeness, may have two opposing effects toward mutual cooperation. If the leader of the hamlet is quite active in promoting and implementing mutual cooperation activities to the community, then this may counter the individual behavior of the urban region. This may be the reason why Kragilan, Krobokan, dan Dladan hamlets have high mutual cooperation. However, on the contrary, if the leader of hamlet tends to be less active in promoting mutual cooperation then this may decrease the mutual cooperation in the community. Finally, the third aspect concerns the migration of people coming in or out of the hamlets. If there are people coming into a hamlet from other regions, who are less familiar with the activities of the hamlet, then this may affect the mutual cooperation values in the community.

The map in Figure 3 above is also made with the rule of color gradation but with different color, i.e.: yellow. The darker yellow color on the map shows a higher level of individual behavior while the lighter yellow color shows the decreasing (lower) of the individual behavior. The highest individual behavior is in Rejokusuman (2) and Tamanan (3) hamlets, which has the lowest mutual cooperation values. The lowest individual behavior is in Kragilan (1), Krobokan (6), and Glagah Kidul (9), which have the highest mutual cooperation values. Hence, the two maps above, viz.: Figure 2 and Figure 3 show opposite results for the level of mutual cooperation and the individual behavior in the hamlets, where the higher the level of mutual cooperation in one hamlet shows a lower individual behavior in the hamlet. As discussed above, globalization (Sari, 2015; Suneki, 2012; Anggorowati \& Sarmini, 2015) and the high activities of people in the city may be the main causes of the spread of individual behavior in the community. 


\section{Conclusions}

From the discussion above, it may be concluded that the strength of mutual cooperation values does not depend on the proximity of the hamlets from the city of Yogyakarta. The hamlets near the city need not be low in their level of mutual cooperation activities. This is proven by the mutual cooperation activities in Kragilan, Krobokan, and Dladan hamlets. Moreover, the mutual cooperation map is reciprocal to the individual behavior of the people in the hamlets, i.e.: the stronger the mutual cooperation values the weaker the individual behavior of the people. This is expected as the mutual cooperation values counter the individual behavior of the community. The results of this study can help the Indonesian government as a policy maker to optimize national development via mutual cooperation values to minimize the individualist nature of society so that social disintegration can be prevented. The government may use similar ways taken by the Kragilan, Krobokan, and Dladan hamlets in promoting and implementing mutual cooperation values in the midst of globalization and high daily activities of people around the city or urban regions.

\section{Acknowledgements}

The authors would like to thank the Student Creativity Program 2019 from Ministry of Research, Technology, and Higher Education for funding this study.

\section{References}

Anggorowati, P., Sarmini. (2015). Implementation of mutual cooperation in the global era (Case Study in Balun Village, Turi District, Lamongan Regency). Kajian Moral dan Kewarganegaraan, 1(3), 39-52.

Bowen, J. R. (1986). On the construction of tradition: Gotong-Royong in Indonesia. The Journal of Asian Studies, 45(3), 545-561.

Creswell, J. W. (2009). Research design: qualitative, quantitative, and mixed methods approaches. Sage Publications Inc.

Effendi. (2013). "The culture of mutual cooperation in the current social change". Journal of Sociology Thinking, 2(1).

Febriani, Tessa, A., Utami, R., Dwandaru, W. S. B. (2019). The factors that causes the shift of mutual cooperation values: Activity level of the community and activeness of the leader. Jurnal Ilmiah Penalaran dan Penelitian Mahasiswa, 3(2), 41-50.

Gea, F.D.S. (2016). Crowdfunding: A new movement for mutual cooperation in Indonesia (Evolutionary review of collective action movements in new media). Proceedings.

Irfan, M. (2017). Crowdfunding as a new meaning of renewable mutual cooperation energy. Share: Social Work Journal, 6(1), 30-42.

Koentjaraningrat. (1961). Some sociological-anthropological observations on gotong-royong practices in two villages $n$ Central Java. Ithaca New York Cornell University.

Mardiasmo, D. Barnes, P. H. (2015). Community response to disasters in Indonesia: Gotong-royong; a double edged-sword. Proceedings of the $9^{\text {th }}$ Annual International Conference of the International Institute for Infrastructure Renewal and Reconstruction. Australia: Queensland University of Technology. 301-307.

Rochmadi, N. (2016). Making the cultural value of mutual cooperation as a common identity. Malang: UNM. Library Repository, State University of Malang. 11/20/2012 9:40

Sari, A. M. (2015). Upholding the tradition of service work as a form of revitalization of mutual cooperation value. Surabaya: UNAIR.

Sudrajat, A. (2014). Cultural values of the Betawi ethnic group as a source of social studies learning. Dissertation, Postgraduate School, Indonesian Education University.

Suneki, S. (2012). The effect of globalization towards the existence of regional culture. Civis 2(1): 307-321. 